\title{
Campaigning for the Prize: The Quests by Sweden and the Kingdom of the Netherlands for Security Council Membership, 2017-2018
}

\author{
Ann-Marie Ekengren | ORCID: 0000-0002-9976-622X \\ University of Gothenburg, Gothenburg, Sweden \\ ann-marie.ekengren@pol.gu.se \\ Ulrika Möller \\ University of Gothenburg, Gothenburg, Sweden \\ ulrika.moller@pol.gu.se
}

Received: 26 June 2020; revised: 17 October 2020; accepted: 10 November 2020

\section{Summary}

Competition for a non-permanent seat in the UN Security Council is getting tougher, not the least between candidates within the Western European and Others Group. This empirical study compares the campaigns carried out by Sweden and the Kingdom of the Netherlands, in order to explain the Swedish victory in the first round of the elections in 2016. A theoretical framework identifies three logics of campaigning: contributions, commitment and competence. The study maps out the features of the campaigns, including organisation, key participants, activities and message. It includes interviews with diplomats and public officials involved in the campaigns, as well as available campaign documentation and concluding reports. A main difference detected between the candidatures is the more active political involvement in the Swedish campaign, which shows the Swedish commitment and competence to serve on the Council. Further use of this theoretical framework on additional cases of international campaigning is encouraged.

\section{Keywords}

Security Council election - non-permanent seat - candidature - international campaigning - Sweden - Kingdom of the Netherlands 
The opportunity to serve as a non-permanent (or elected) member of the UN Security Council (UNSC) is becoming increasingly attractive. Symptomatic of this trend, campaigning begins years ahead of the election and is carried out more intensely, especially in regional groups with contested slates. ${ }^{1}$ To illustrate, for the 2017-2018 term three candidates competed for the two seats reserved for the Western European and Others Group (WEOG): Sweden, the Kingdom of the Netherlands and Italy. A contested slate between these three wealthy and multilaterally committed countries paved the way for very active campaigning. Initially, many observers appointed Italy as the stronger candidate, leaving Sweden and the Kingdom of the Netherlands to compete over the second seat. ${ }^{2}$ Later on, with little more than a year left to gather support, many Ambassadors in New York described Sweden as the candidate which had fallen behind and would end up defeated. Contradicting this prediction, the Swedish team celebrated a first-round victory when the election took place in the UN General Assembly (UNGA) on 28 June 2016. For the second seat, support for the Netherlands and Italy was tied, even after five rounds of voting. A situation they resolved through a split-term agreement. ${ }^{3}$

This article aims to offer an explanation of why Sweden won the 2016 UNSC election. This study zooms in on campaigning as a neglected factor in previous studies on the selection of non-permanent members to the Security Council. ${ }^{4}$ It suggests that the existing research could benefit from a clearer explanatory focus and from structured case comparisons. The article contributes in this regard by identifying relevant descriptive categories and by designing a theoretical framework for a comparison of the campaigns by the Kingdom of the Netherlands and Sweden to explain the variation in electoral outcome. It suggests that this theoretical framework is also applicable to other types of campaigns which states conduct in their competition for international office. To specify, international office seeking is one means by which states seek active participation within the international organisations that they hold membership. In the case of the United Nations, elections in the UNGA decide the members of the Economic and Social Council, members of the Human Rights Council, as well as the non-permanent members of the Security Council. There

1 Malone 2000. The study by Kennedy and McMahon 2005 highlights this trend for a single case over time; Ireland's term in the Security Council 1962 was preceded by a lack of campaigning, in contrast to Ireland's later terms.

2 Tahzib-Lie and Reinder Rosing 2019, 469-472, 477-478.

3 Security Council Report 2016; Tahzib-Lie and Reinder Rosing 2019, 469.

4 Sievers and Daws 2014; Ekengren, Hjorthen and Möller 2020. 
are also elections to members of subsidiary bodies, in the UNGA or within the UN body to which the subsidiary belongs. Terms for these positions are generally one to two years. Although differences in the nomination and election process exist, active seeking of support by candidates is common practice. Arguably, the elections to the Security Council are of particular importance to a large number of UN Member States, as a successful candidature comes with the rare opportunity to participate in decision-making on matters of international peace and security. Although the candidates strive for guarantees of support through written vote agreements, the secret ballot accounts for uncertainty about the outcome. Several campaigns have found that their estimates of support turned out to be exaggerated on the day of the election. ${ }^{5}$ One reason for discrepancies between estimates and outcome is that the received promises of support did not come from the highest political level. The circumstance that votes commonly are cast by the Permanent Representative in New York also brings uncertainty, especially about votes from Member States with weaker political institutions which may account for a lack of political steering and control of diplomacy.

While this development certainly highlights the increasing importance of soft power within foreign policy, the literature on this particular foreign policy activity, and how it can be explained, is very limited. ${ }^{6}$

This article begins with an overview of earlier research on the election of non-permanent members to the Security Council. On basis of that earlier research, the article identifies four relevant descriptive categories for comparison. These categories are: organisation, key actors, activities and message. The literature also helps in designing a theoretical framework which separates between three logics of campaigning. These logics are: demonstrating contributions, proving ideational commitment and claiming competence. The categories help to structure the comparison and the framework enables inferences with regard to variations between campaigns which may account for the electoral outcome. The final section of the article concludes why Sweden was more successful in the UNSC election, discusses the relevance of the framework and summarises some advice for future campaigning.

5 The Finnish defeat in the 2012 election is one example especially paid attention to by the International Peace Institute report 'Taking Stock, Moving Forward'. International Peace Institute 2012.

6 Neumayer 2008; Byrne 2011, 14-16; Wiseman 2011, 711. 
2

\section{Studying the Campaigning for an Elected Seat on the Security Council}

To select non-permanent members of the Security Council, the UN Charter instructs members to pay special attention to candidates' contributions 'to the maintenance of international peace and security and to the other purposes of the Organization' (Article 23 (1)). Previous research on the candidatures for a non-permanent seat confirm the relevance of the Charter instructions but point to other factors as more important. To specify, among the few statistical studies on UN elections, the most recent analysis by Axel Dreher and colleagues on determinants to frequent membership of the Security Council points primarily to the importance of population and wealth but detects influence from a 'peace norm' and a 'turn-taking norm.' ${ }^{7}$ Earlier statistical studies on UN elections identify the importance of 1) contributions to the UN, 2) the image as a 'good' member of the $\mathrm{UN}$ and 3 ) the personality and reputation of individual delegates in the competitions for office within the organisation. ${ }^{8}$

To describe and discuss the results, beginning with the older studies, it is worth to consider that campaigns have become more competitive in the past decade. Still, in this tougher climate for candidates, the actual contributions as well as the image of a good member should be equally relevant today. The opportunity for substantial contributions probably also is one reason for why wealth is such a relevant factor in the more recent research. Further, this article suggests that wealth produces additional advantages for a candidate in terms of a larger budget for each campaign, and also for a stronger diplomatic network through embassies in more countries as well as Permanent Representations in the UN headquarters cities. By 'peace norm', Dreher et al. refer to the UN's main mission to prevent conflict and to promote peace, and the above-mentioned instructions for Member States to take the peace credentials into consideration when voting in the UNSC election. One effect is that members engaged in civil war are less likely to be elected members of the Council. By a 'turn-taking norm', Dreher et al. refer to the practice of a set order for candidatures in some of the regional groups and, in competitive races, the advantage for first-time candidates and candidates with longer spells outside the Council. ${ }^{9}$

Explanations in previous research for why some states are more successful in the elections of non-permanent members cannot easily account for the Swedish win. To specify, both Sweden and the Netherlands are wealthy states

7 Dreher et al. 2014, 53, 75, 77-79.

8 Singer and Sensenig 1963; Maas Weigert and Riggs 1969.

9 Dreher et al. 2014. 
that have been able to afford and prioritise substantial contributions to the UN, which is also reflected by their image and reputation as multilateral states. They are also peaceful states which have served in the Security Council several times. The differences in terms of the Kingdom of the Netherlands as being more populous with a larger economy speak to its advantage. ${ }^{10}$ This article suggests that the inability to explain the Swedish win with factors identified in earlier research points to the relevance of examining the actual campaigning.

While this article suggests a comparative approach, the few more recent studies which explicitly address some campaign features are either single case studies, mainly focussing on the term rather than the candidature, or ones which address differences between campaigns only by illustration. ${ }^{11}$ A notable exception from analysis of one candidature/term at a time is the study by David Chapnick which includes all Canadian candidatures, with the exception of 2020. Interestingly, even if the domestic politics of international office is beyond the scope of this article, Chapnick's study reveals a Canadian politicisation of non-permanent membership over time. ${ }^{12}$ However, all studies give us valuable help in identifying important campaign categories for further study. They describe how campaigns are organised in the capital, and carried out through different activities around the world, but with UN headquarters in New York as an especially important site. ${ }^{13}$ These studies also give us reason to assume that quality and attractiveness of campaigns can matter. For example, David Malone and Caitlin Byrne underline the importance of the formulation of the campaign messages. ${ }^{14}$ To specify, Byrne argues that the message can raise awareness of and improve a country's reputation but that a lack of political commitment to a message can also do harm in a campaign. ${ }^{15}$ Moreover, Adam Chapnick, Mary Whelan and Caitlin Byrne all describe the importance of having skilful people running the campaign. Chapnick highlights the relevance of a well-respected Permanent Representative as well as the contributions by individual politicians for the outcome of a campaign. ${ }^{16}$ Whelan and Byrne explain that referred skills are to know when to listen to others and when to pursue

10 By the time of the election in 2016, Sweden had 107 international missions, compared to 144 for the Netherlands and 205 for Italy. Lowy Institute 2016.

11 Thakur 1996; Malone 20oo; Whelan 200o; Byrne 2011; Copeland 1999, 2010; Gillissen 20o6, 23-24; Langmore 2013, 104-107; O'Brien 2015; Langmore and Farrall 2016, 59-61; Thorhallsson and Eggértsdottir 2021.

12 Chapnick 2019.

13 Malone 2000; Langmore 2013.

14 Malone 2000, 8; Byrne 2011, 8, 19-21.

15 Byrne 2011, 8, 21.

16 Chapnick 2019, 11, 115, 151, 176-177. 
their own message. ${ }^{17}$ International campaigning includes activities which otherwise are far from traditional diplomacy. ${ }^{18}$ Byrne argues that these activities are important to attract public attention within the targeted diplomatic and political community. ${ }^{19}$

The relevance of the features addressed above is also confirmed in literature on other types of campaigns, including national election campaigning and Olympic Games site decisions. These features are: 1) organisation, ${ }^{20} 2$ ) individual politicians' skills ${ }^{21}$ and 3) a coherent message. ${ }^{22}$ In addition, there is relevance in mapping out the activities of the campaign. This article describes these categories below to clarify how this study can bring additional knowledge about state campaigning for a non-permanent seat in the Security Council. With respect to organisation, previous studies on UNSC candidatures suggest that the campaigns are set up and run from the state's capital, with the Permanent Mission in New York as the other important unit. ${ }^{23}$ We need to learn more about the size of these units and their relationship to each other. With respect to key participants, the campaigns seem to engage a mix of politicians, public officials and diplomats. ${ }^{24}$ We need to learn more about the relevance of political versus diplomatic participation, as well as whether there are additional important actors and what role they play. With regard to activities, the campaigns are global in scope in the sense that events occur in the capitals and in New York, as well as in embassies around the world. The participants in the campaigns also visit targeted countries for the sake of gathering support. ${ }^{25}$ We need to learn more about the relevance and purpose of these different activities. With respect to a coherent message, it is relevant to consider candidates' contributions to the UN and their image as 'good' members of the UN. It makes sense that candidates seek to communicate past and current commitments since the UN Charter specifically instructs Member States to pay

\footnotetext{
17 Whelan 200o, 19-20; Byrne 2011, 23-25.

18 Wiseman 2011; Melissen 2011.

19 Byrne 2011, 14.

$20 \quad$ Panebianco 1988; Hernson 2009.

21 Van der Brug and Mughan 2007.

22 Persson 2000; O'Shaughnessy 2002; Sussman 2005.

23 Langmore 2013.

24 Langmore 2013.

25 Malone 2000; Langmore 2013.
} 
special regard to contributions to international peace and security. This relates to the relevance of a good national reputation but David Malone suggests that relying mainly on an 'excessively complacent view of their own standing' might very well head towards a defeat. ${ }^{26}$ Rather, Malone argues that candidates 'need to develop one or two themes on which they can hammer away consistently'. ${ }^{27}$ We need to learn more about the content of these messages, such as the main values and specific topics, as well as how they fit with the broader foreign policy.

On basis of the research addressed above to account for variation in electoral outcome from campaigning, this article suggests that there are three logics inherent to the campaigns states' conduct. In essence, by their campaigns states seek to reveal their contributions, their commitment and their competence. According to the first logic, we expect candidates to focus on communicating their previous and current contributions to the UN. They might seek to spread their multilateral merits, or UN Curriculum Vitae (CV), to prove the strength of their candidature. This is of immediate relevance to the recommendation in the UN Charter that Member States consider contributions to international peace and security in these elections.

According to the second logic, we expect candidates to focus on communicating their commitment through a message that specifies certain values, themes and challenges. Typically, the values, themes and challenges resonate with some of their strongest merits.

According to the third logic, we expect candidates to focus on communicating the relevant competences and skills. Typically, relevant skills resonate with the values, themes and challenges identified by the message, which helps to shed light on contributions.

Thus, while each of these logics may be followed on its own terms, when combined they reinforce the attractiveness of the campaign. This article suggests that there is a relevant difference between the first logic and the two remaining ones. While the communication of contributions may be carried out by public officials and diplomats, the task to convince on commitment and competence requires actively involved politicians. In contrast, a campaign carried out by dedicated and competent diplomats and senior officials

26 Malone 2000, 8.

27 Malone 2000, 8. 


\begin{tabular}{lll}
$\begin{array}{l}\text { Demonstrating } \\
\text { contributions }\end{array}$ & $\begin{array}{l}\text { Proving ideational } \\
\text { commitment }\end{array}$ & Claiming competence \\
\hline
\end{tabular}

$\begin{array}{lll}\begin{array}{l}\text { Focus on previous and } \\ \text { current contributions } \\ \text { to the UN and the } \\ \text { multilateral order. }\end{array} & \begin{array}{l}\text { Focus on a clear and } \\ \text { consistent message, by } \\ \text { promoting specific themes } \\ \text { and values and defining } \\ \text { certain global challenges. }\end{array} & \begin{array}{l}\text { Focus on skills and expertise } \\ \text { among politicians and } \\ \text { diplomats. }\end{array} \\ \begin{array}{l}\text { Communicating } \\ \text { multilateral merits. }\end{array} & \begin{array}{l}\text { Displaying dedication to } \\ \text { the message. }\end{array} & \begin{array}{l}\text { Displaying competence with } \\ \text { regard to the themes, values } \\ \text { and challenges identified } \\ \text { through the message. }\end{array} \\ \end{array}$

SOURCE: AUTHORS' TABLE

could potentially face questions as to why their government is not investing its time and efforts, and whether such thin engagement will characterise the term if elected. This article summarises these three logics in Table 1 above, and analyses differences between the two campaigns on basis of this theoretical framework.

Table 1 shows this article's theoretical framework and the three logics: demonstrating contributions, proving ideational commitment and claiming competence. In each column, the table summarises the main campaign features of each logic. If campaigns demonstrate contributions, they do so by focussing on previous achievements; if campaigns prove ideational commitment, they do so by highlighting specific values; and, if campaigns claim competence, they do so by focusing on competences and skills.

\section{5}

\section{Cases of Comparison}

This study is a comparison between Sweden and the Kingdom of the Netherlands as the most similar cases among the WEOG candidatures in the 2016 election but with different outcomes in the election. The study examines the variation in the election outcome by detecting differences between two countries' campaigns. Both states are European (EU) members and have identities as welfare states belonging to the West. They are also among the smaller 
states with substantive multilateral merits, strong on foreign aid and peacekeeping. Both states have considerable previous experience of serving in the Security Council. ${ }^{28}$

The comparison relies on a variety of sources: political statements, pamphlets and other materials produced during the campaigns; assessments once the campaigns were completed; and interviews with public officials and diplomats involved in the campaigns - thirteen for Sweden and five for the Kingdom of the Netherlands.

\section{$6 \quad$ Sweden}

\subsection{Organisation of the Campaign}

The position of Foreign Minister during the Swedish candidature was first held by Carl Bildt (Moderate Party) (2006-2014) and then by Margot Wallström (Social Democrats) (2014-2019). These two individuals accentuated the diverging views of their respective coalition governments on the role of the UN in Swedish foreign policy, as well as how Sweden should go about winning a seat on the Security Council. Bildt made a political statement out of the Swedish candidature by launching a 'thin' campaign, mainly restricted to the circulation of international merits summarised as the Swedish UN CV. One person became responsible for co-ordinating the candidature at the Ministry of Foreign Affairs in August 2012. It took another two years, until September 2014, to have two staff members in place at the Swedish Representation in New York - a diplomat responsible for co-ordinating the campaign in New York and an election officer. ${ }^{29}$ Once in office, Wallström revised Sweden's campaign strategy in favour of a more ambitious approach, with full support from the new Prime Minister, Stefan Löfven (Social Democrats). The government declaration in October 2014 highlighted the UN candidature, thereby implying heightened priority. At this stage, not only the Foreign Ministry but also the Government Offices of Sweden were becoming involved in the work. ${ }^{30}$

The Secretariat for the Swedish campaign was located at the Ministry of Foreign Affairs in Stockholm. The Secretariat in Stockholm was set up during the autumn and winter of 2014, initially consisting of six people: one manager, four co-workers and one assistant; two additional staff had joined once the

28 Security Council Report 2016.

29 Cronenberg-Mossberg 2017.

30 Interviews 2, 3, 11. (Interviews 1-13 are with Swedish diplomats; Interviews 14-18 are with Dutch diplomats.) 
campaign approached the final phase. The initial division of labour made each co-worker responsible for one geographical region. The two newest staff members were responsible for 1) keeping track of the diplomatic interactions and the growing number of voting agreements reached, and 2) handling the documentation of the campaign and other issues raised in the domestic debate around the candidature. ${ }^{31}$ An additional centre was located at Sweden's Permanent Representation to the United Nations in New York. Intense and friendly contacts between Stockholm and New York characterised the period of active campaigning. The team in New York appreciated that the Secretariat in Stockholm trusted the judgments and plans made at the New York campaign site. ${ }^{32}$ The campaign also engaged Swedish embassies around the world, as well as the delegations in Brussels and Geneva. The campaign sought to compensate for Sweden's weak bilateral diplomatic representation by making the most out of 2015 as a year with a busy multilateral schedule. The reach of the campaign was increased by using a number of high-profile meetings, including the 2015 UN Climate Change Conference (COP 21) in Paris and Financing for Development in Addis Ababa, as opportunities to promote the Swedish candidature. ${ }^{33}$

In March 2015, there was a replacement of the Permanent Representative to the UN, with Ambassador Olof Skoog taking on the position in New York. The campaign unit at the Swedish Representation also got two additional staff members in 2015: one communications professional and one assistant. As the campaign intensified, it came to permeate most of the work at the mission in New York. The most important position among the non-diplomatic staff in New York was the election officer. During the intense concluding part of the Swedish campaign, the team in New York even had two election officers. With only weeks left until the election, there were twice-daily update meetings attended by a majority of the people present at the Representation. ${ }^{34}$ To estimate the gathered support, the campaign elaborated a tool, where they described other countries in terms of certain (in Swedish: säkra), positive (in Swedish: positiva), uncertain (in Swedish: osäkra) and negative (in Swedish: negativa). This was internally referred to as 'the SPON list' (säkra, positiva, osäkra, negativa), relying on coherence in the received responses over time between different diplomatic and political levels. ${ }^{35}$

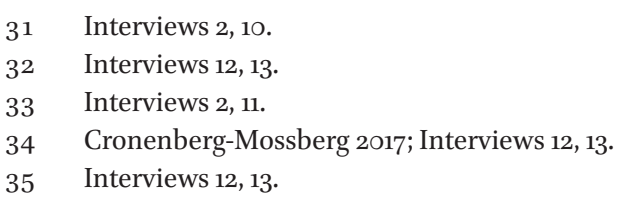




\subsection{Key Participants}

The political parties which formed the liberal-right coalition government (2006-2010, 2010-2014) stood behind the 2004 announcement of the candidature in their role as political opposition. As a government, they turned out to be more reluctant to move the candidature forward. The Prime Minister, Fredrik Reinfeldt (Moderate Party), showed no special interest in the matter. Critical voices claimed that contested slates within the WEOG displayed undesired rivalry between members of the EU. The coalition government consisted of parties whose hearts and minds were invested in European integration. Carl Bildt contributed to the debate by promoting a rotation schedule for the EU members. The larger members of the EU refuted a rotation schedule as they aim for representation on the UNSC on a more frequent basis. As an additional approach, Bildt promoted a 'thin' campaign to keep it clean and save it from the rampant costs of extensive diplomacy and politicians on the move. ${ }^{36}$

In contrast, the 2014 governmental declaration pronounced an active pursuit of the candidature. ${ }^{37}$ The new Prime Minister, Stefan Löfven, was among the critical voices against the concept of a thin campaign. The Social Democrats considered this approach a profound lack of interest in the candidature. ${ }^{38}$ Löfven substantiated his political dedication to the candidature by actively participating in the campaign. The other two most active ministers were Foreign Minister Margot Wallström and Minister for International Development Cooperation Isabella Lövin (Green Party). Wallström's Cabinet Secretary, Annika Söder, and Lövin's Cabinet Secretary, Ulrika Modéer, were also intensely involved. They all raised the candidature in their external contacts planned for other purposes and travelled for the main purpose of promoting the candidature. Löfven's political advisor, Efraim Gomez, was important in engaging Löfven's interest in the campaign and acting as a link between the Ministry of Foreign Affairs and the Government Offices.

The position of Campaign Manager was first held by Anna-Karin Eneström and then by Niklas Kvarnström. Carl Skau was responsible for the campaign in New York. Olof Skoog was appointed Permanent Representative in March 2015, with only fifteen months left until the election. The obligatory first courtesy visit to meet with colleagues gave an instant opportunity for the new Permanent Representative to raise the Swedish candidature. ${ }^{39}$ By taking on the position

\footnotetext{
36 Interviews 1, 3, 5.

37 Government Declaration (Sweden) 2014.

38 Löfven and Ahlin 2013.

39 Interviews 12, 13.
} 
as Chair of the Peacebuilding Commission, Skoog also had the opportunity to bring immediate visibility to the Swedish Delegation and candidature.

The candidature also engaged Swedish Ambassadors around the world. To further increase the number of representatives actively promoting the candidature, the Secretariat in Stockholm recruited a group of former politicians and senior diplomats. These Special Envoys consisted of former Prime Ministers Göran Persson (1996-2006) and Carl Bildt (1991-1994) (also the most recent former Minister of Foreign Affairs, 2006-2014), former Minister of Foreign Affairs Lena Hjelm Wallén (1994-1998) and former diplomats Marika Fahlén, Pierre Schori and Henrik Salander. Persson was never actively involved in the campaign but was mentioned as a figurehead. On rare occasions, Crown Princess Victoria attended as an additional highlight to activities related to the campaign which took place in Stockholm.

\subsection{Campaign Activities}

The Swedish candidature was not very active with regard to voting exchange agreements, the main activity during the initial phase of a candidature. While the diplomatic deliberations that lead to an agreement can take place in different locations, the interaction between Permanent Representatives in New York is particularly important. The close and recurrent dialogue between the Nordic Permanent Representatives in New York enabled Ambassador Skoog, in March 2015, to draw the disappointing conclusion that the Swedish candidature for a 2017-2018 seat had fewer agreements to rely on than the Norwegian candidature had for a 2021-2022 seat. Even though the number of vote exchange agreements was initially low, support increased once the campaign intensified. In October 2015, Sweden had confirmed support from 101 countries, and 32 of these were considered certain. In May 2016, the support had increased to 129 countries, of which 36 were regarded as certain. Just a few days prior to the election, confirmed support had reached 140 countries, with 39 certain countries. ${ }^{40}$

The Member State speeches at the opening of the General Assembly annual sessions are the public push of the candidature in New York. It is usually the Head of the Government or the Foreign Minister who delivers the speech. However, neither Foreign Minister Bildt in 2012, nor Prime Minister Reinfeldt in 2013, raised the Swedish candidature in their speeches. The speech in the 2014 session, by the Swedish Permanent Representative Mårten Grunditz was the first to mention the Swedish candidature. His main points in reference to the candidature were that it had Nordic support and that the UN needed further

Lidén 2016. 
reform to meet global challenges. ${ }^{41}$ In 2015, Prime Minister Löfven launched the Swedish candidature further and emphasised Sweden as a champion of small- and medium-sized states, aiming for equality and fair representation of all states. ${ }^{42}$

The Swedish campaign paid special attention to the group of Small Island Developing States (sIDs), a group Prime Minister Löfven had met with in the autumn of $2014 .^{43}$ The Swedish campaign took an active approach vis-á-vis SIDS and others at three major multilateral meetings in 2015. These multilateral meetings came with the opportunity to reach representatives of countries where Sweden did not have an embassy and were attended by members of the government such as Foreign Minister Wallström and - even more importantly — Prime Minister Löfven.

In addition to the efforts to promote the candidature in multilateral settings, members of the Swedish government travelled extensively to enable bilateral and regional meetings. During the last six months before the election, Wallström visited Kongo-Kinshasa, the Maldives, Sri Lanka, Palau and Micronesia, the United Arab Emirates, Georgia, Armenia and Azerbaijan. Several other members of the government contributed to the campaign by attending political meetings. Prime Minister Löfven made three visits to Addis Ababa and four to New York to promote the candidature. ${ }^{44}$ Wallström visited the Caribbean Community (CARICOM) conference of the Council for Foreign and Community Relations (COFCOR) twice, developed a special forum for female Foreign Ministers and invited female Permanent Representatives in New York to a special meeting. The campaign welcomed 27 PRs to Stockholm to address topics including development, conflict prevention, and climate. During this visit, the PRs also got to meet with the Swedish Crown Princess couple. Noteworthy, is that the event sparked a critical debate on aid spending, but a parliamentary audit concluded that it did not break from prevailing rules. Sweden also welcomed many Foreign Ministers to Stockholm during the last year. ${ }^{45}$

The Special Envoys were also sent to selected destinations to attend multilateral and bilateral meetings for the sake of gathering support for Sweden. They were not instructed in detail with regard to the main themes of the campaign. Rather, their main contribution consisted of their established networks and their special expertise. Broadly, these senior politicians and diplomats were encouraged to engage in dialogue about the substantive issues

\footnotetext{
41 Grunditz 2014.

42 Löfven 2015.

43 Interview 2.

44 Lidén 2016.

45 Lidén 2016; Cronenberg-Mossberg 2017.
} 
in which they held expertise. Although Stockholm gave few instructions to these Special Envoys, the documentation of their contacts was more careful. To illustrate, Salander held 53 talks with diplomats and politicians during the Review Conference of the Parties to the Treaty on the Non-Proliferation of Nuclear Weapons. He reported them to Stockholm in two written memos, each 12-15 pages in length.

\subsection{Campaign Message}

The initial discussions on message at the Ministry of Foreign Affairs during Bildt's time in office concluded that the campaign should focus primarily on merits. Rather than a regular campaign, it was believed that Sweden should seek support mainly through the circulation of its UN CV summarising contributions to the United Nations over the years. The UN CV listed Swedish personnel in peacekeeping, economic support for development, main policy priorities and positions and engagements in key areas such as peace building, human rights, sustainable development and gender equality. ${ }^{46}$

In shaping the active part of the campaign, several members of the team pinpointed the importance of trustworthiness, which required that the message reflected Sweden's general foreign policy. ${ }^{47}$ 'The most important thing was to be honest about who Sweden was, and what we wanted to achieve in the UN'.48 Sweden should appear as 'constructive, listening and transparent'. It was relevant to be seen as a good representative of the entire General Assembly and especially of the UN members which had never been elected to the Security Council. The campaign also sought to display a diversified portfolio, not restricted to security, to earn the opportunity to become the representative of as many members as possible. ${ }^{49}$

It remained important to display Sweden's past of solid contributions to the UN for the sake of international peace and security. The campaign pamphlet repeated many of the merits stated in the UN CV, such as the number of Swedish men and women who had served within the UN, Sweden's top ranking on the UN donor list and the Swedish Official Development Assistance (ODA). In accordance with the UN CV, the campaign highlighted peacebuilding, respect for international law, human rights and development as high-priority issues. On peacebuilding, the Swedish campaign emphasised the involvement of women in conflict resolution. On sustainable development, the Swedish campaign focused on climate change action and emphasised Sweden's long

\footnotetext{
46 Cronenberg-Mossberg 2017, Annex.

47 Interviews 2, 10.

48 Interview 2.

49 Interviews 1, 3, 7.
} 
commitment to this issue. Extensive involvement in the campaign by Minister of International Development Cooperation and Climate Lövin substantiated Sweden's current dedication in this area. On UN reform, the campaign was explicit on improved transparency and efficiency as goals. The campaign was also careful to spell out that Sweden was ready to serve because twenty years had passed since its last time and both other candidates had served more recently.

To present and promote Sweden, the campaign began to use the slogan 'Global Commitment, Independent Voice'. The Secretariat received acceptance of the slogan at the political level but it was heavily criticised once it was made public. The political opposition described the slogan as inaccurate - Sweden was not an independent voice but part of the European foreign policy - and the slogan was thereby playing down Sweden's commitment to the EU. ${ }^{50}$ The debate resulted in a political decision to phase out the description of Sweden as an independent voice and to replace it with Sweden as a voice with integrity.

The answers given in this study's interviews revealed two different descriptions of the messages in relation to the receiving Member States. Some interviewees stressed that the message was similar in all settings and to all receiving Member States. Others said that some parts of the message were used more frequently to specific groups of Member States. For example, in talking to small island states, Sweden emphasised its dedication to climate change action. In talking to a country in Africa recently affected by conflict or war, Sweden focussed more on peacekeeping and emphasised, for example, the importance of women's role in peace negotiations. However, these were both important components of the broader Swedish message, as well as issues where Sweden had an especially strong record of involvement.

\section{The Kingdom of the Netherlands}

\subsection{Organisation}

The Netherlands had several different coalition governments during the UNSC candidature of the Kingdom of the Netherlands (2005-2016). The governments of Prime Ministers Jan Peter Balkenende (Christian Democrats) and Mark Rutte (People's Party for Freedom and Democracy) were consistent on the high relevance of the candidature. The candidature was on behalf of the Kingdom of the Netherlands, and thus included the four countries: the Netherlands, Aruba, Curaçao and Sint Maarten. The Secretariat for the Kingdom's campaign was located at the Ministry of Foreign Affairs in The Hague. The Permanent

Interviews 1, 2, 10. 
Representation to the United Nations in New York was the other important unit. The Hague Secretariat began to emerge in 2013, with two staff members and one intern. It grew gradually; in March 2014 there was a new campaign manager in place, and by the time of the election there were eight to ten people on staff. The campaign was co-ordinated from The Hague but in close contact with New York, which contributed substantial input on the shape of the campaign. The campaign team in New York had seven members, including two interns, during most of the active phase. The number increased to fifteen members in the final weeks ahead of the election. ${ }^{51}$

The 2013 Dutch speech in the General Assembly, delivered by Foreign Minister Frans Timmermans (Labour Party), was the first to launch the candidature in New York. The Kingdom of the Netherlands was introduced as 'your partner for peace, justice and development'.52 Almost three years ahead of the election, this launch coincided with the inauguration of Ambassador Karel J.G. van Oosterom as Permanent Representative of the Kingdom of the Netherlands. The diplomatic work to reach vote agreements had been going on since the announcement of the Dutch candidature in 2005. From the autumn of 2013, winning support through bilateral contacts was a main activity of the new Permanent Representative. ${ }^{53}$

The campaign also engaged the Dutch Embassies around the world, as well as the diplomatic missions in Brussels and Geneva. Referred to as 'the golden triangle', The Hague, New York and the embassies were the three main pillars of the campaign. There was a systematic approach in terms of ensuring distribution of additions to the campaign to all locations at the same time. It is noteworthy that the capitals of the Caribbean countries of the Kingdom were not explicit in this strategic figure, even though co-ordination between the capitals took place.

The campaign aimed to develop contacts with as many individuals as possible at all political and diplomatic levels. The campaign took into account that the decision-maker could vary between countries. To keep track of the established contacts and estimated support, the Secretariat established a database to which all members of the campaign had access, including to a list of the identified decision-makers. The estimations of support relied on a system of confirming and reconfirming on different levels. When the campaign

$51 \quad$ Interviews 14, 17.

52 Timmermans 2013.

53 Interviews 14, 18. 
organisation detected inconsistencies between levels, this was taken as a sign of weak or absent support which helped to identify relations in need of additional work. ${ }^{54}$

\subsection{Key Participants}

The active part of the candidature took place with Mark Rutte as head of a coalition government between his conservative liberal People's Party for Freedom and Democracy and the Social Democrats. ${ }^{55}$ Foreign Minister Frans Timmermans launched the candidature in the General Assembly in September 2013 , with a special focus on the legal order supported and promoted by the Netherlands. ${ }^{56}$ The following years of active campaigning took place with Bernt Koenders (Labour Party) as Foreign Minister. Ambassador Bahia Tahzib Lie was campaign manager in The Hague, and Frans Kemperman was responsible for the campaign in New York.

The strategic concept of 'the golden triangle' (The Hague, New York and diplomatic missions) captured the relevance of the Ambassadors around the world as campaign workers. The Permanent Representative in New York was of special importance. The arrival of Karel J.G. van Oosterom in August 2013 marked the start of the campaign in New York. Van Oosterom had already been involved in the candidature in his previous position as Director-General for Political Affairs in the Ministry of Foreign Affairs. Among the members of the government, the Foreign Minister was the member of the government most involved in the campaign. The candidature also engaged ministers from the Caribbean part of the Kingdom. The campaign aimed for active involvement by members of the Dutch government but that turned out to be challenging. One restraining factor was that the peak of the campaign coincided with the Netherlands' Presidency of the Council of the European Union (1 January to 30 June 2016). To further increase the number of representatives actively promoting the candidature, the Secretariat in The Hague recruited a group of former politicians and senior diplomats. These Special Envoys included the senior diplomats Herman Schaper and Laetitia van den Assum. Schaper was the former Permanent Representative in New York (2009-2013), and van den Assum had Kenya, Mexico and the United Kingdom among her previous postings. ${ }^{57}$

\footnotetext{
54 Interviews 14, 15, 16.

55 Dutch Foreign Ministers in office: Christian Democrat Ben Bot (2003-2007), Christian Democrat Maxime Verhagen (2007-2010), Liberal Uri Rosenthal (2010-2012), Social Democrat Frans Timmermans (2012-2014) and Social Democrat Bernt Koenders (2014-2017).

56 Timmermans 2013 .

57 Interviews 14, 15, 16.
} 
On some occasions, members of the royal family were involved in activities related to the campaign. Most notably, the Dutch speech in the General Assembly in 2015 was delivered by King Willem-Alexander. This placed the Dutch speech earlier in the session since the diplomatic protocol places Heads of State before Prime Ministers. Prime Minister Rutte, Foreign Minister Koenders and Queen Maxima also attended this UN session.

In addition to members of the royal family, the Dutch campaign involved some celebrities. In his role as the UN Global Advocate for the Elimination of Mines and Explosive Hazards, actor Daniel Craig (who played James Bond) participated in campaign activities supporting the topic. Ambassador van Oosterom tweeted that he was 'thrilled — perhaps even stirred, not shaken' to raise awareness with Craig on demining issues.

\subsection{Campaign Activities}

The phase of active campaigning began with Foreign Minister Frans Timmermanns's speech at the 2013 session in the General Assembly, which introduced the slogan 'The Kingdom of the Netherlands: Your Partner for Peace, Justice and Development'. The speech presented Dutch contributions to the UN and identified main challenges to the global order. ${ }^{58}$ At this point, Ambassador van Oosterom began his mission to meet with colleagues. Before every meeting, members of the campaign team held briefing sessions with the Ambassador to go over the issues to be discussed but the meetings also had a clear focus on the main message as presented in the slogan. The Ambassador's reports back on the discussions from each meeting were included in the database to keep track of contacts and estimate support. Van Oosterom held around eight meetings per week, with the target of meeting each colleague two to three times ahead of the election. ${ }^{59}$

In addition to the bilateral diplomatic contacts, a number of activities took place in New York to present the Kingdom of the Netherlands' achievements and priorities within the UN system. The campaign also hosted a number of events to reach politicians and Ambassadors outside of the New York diplomatic community, such as in The Hague and other capitals, as well as in Brussels. These occasions displayed the slogan and the main message for the candidature, and used social media to report the activity. Other topics raised in connection with the campaign included climate change, infrastructure, development issues of the Security Council, and Syria. While lunch-meeting with speakers' was a regular format, the campaign in New York also organised

58 Timmermans 2013.

59 Interviews 14, 18; Tahzib-Lie and Reinder Rosing 2019. 
a boat trip on the East River with 40 Permanent Representatives on board for the purpose of displaying Dutch activities on water projects. The campaign arranged events in New York such as a soccer game involving Dutch players ${ }^{60}$ and meetings in The Hague on three different occasions, hosting around fifteen Permanent Representatives at each. These meetings aimed at displaying The Hague as 'a city of peace and justice' hosting a number of UN bodies and demonstrating Dutch experience and expertise; for example, on water management issues. During these meetings, the Permanent Representatives met with Prime Minster Rutte as well as with King Willem-Alexander. ${ }^{61}$ The campaign also arranged a meeting in Aruba for Ambassadors in the siDs group to address sustainability issues. Foreign Minister Koenders launched the candidature at a reception hosted by the embassy in Brussels for diplomats from the African, Caribbean and South Pacific states. In June 2016, with only weeks left until the election, the Dutch Ministry of Foreign Affairs hosted a reception in The Hague for Ambassadors located in The Hague, in London and in Brussels. Minister for Foreign Trade and Development Cooperation Lilianne Ploumen attended the event, as did representatives of Aruba, Curaçao and Sint Maarten. ${ }^{62}$

\subsection{Campaign Message}

The Dutch campaign for a seat on the Security Council relied on the Netherlands as a country with a genuinely multilateral identity, solid reputation in matters related to international law and justice and a long record of substantive contributions to development and UN peacekeeping. It also made the most out of the Kingdom of the Netherlands as a kingdom of four countries: the Netherlands, Aruba, Curaçao and Sint Maarten, sharing experiences with European as well as Caribbean countries. ${ }^{63}$ The three Caribbean countries have experiences in common with many small developing island states. It was important to the campaign to express a genuine interest in dialogue and partnership between countries regardless of their size. The campaign also paid special attention to issues related to sustainable development, climate change and water management. The need for Security Council reform, explicitly asking for better representation for African countries, and the importance of gender equality for development were other frequently raised topics.

\footnotetext{
6o Interviews 14, 15 .

61 Interviews 14, 17.

62 Stylianides 2016.

63 One possible complication was the risk that mentioning their overseas territories would antagonize small independent island countries.
} 
The Dutch campaign message was summarised by the slogan "The Kingdom of the Netherlands: Your Partner for Peace, Justice and Development'. The slogan, formulated by the campaign office in The Hague during the preparatory phase, became a consistently used introduction to the many different activities during the second and more intense phase of the candidature. All of the annual speeches in the General Assembly from 2013 to 2016 referred to the slogan and substantiated its three pillars. In the 2013 Dutch speech in the UNGA, Foreign Minister Frans Timmermans launched partnership as the cornerstone of the Dutch candidacy, along with the reassuring words directed specifically to the Secretary-General that 'We will join you on the road to peace, justice and development.64

In the 2014 Dutch speech in the UNGA, Prime Minister Mark Rutte repeated that 'the Kingdom of the Netherlands, your partner for peace, justice and development, is a candidate for a non-permanent seat on the Security Council in 2017 and 2018.' Prime Minster Rutte substantiated the message of the slogan by emphasising the Netherlands' established dedication to the development of international legal order and consistent contributions to UN peacekeeping missions. ${ }^{65}$

The 2015 Dutch speech in the UNGA was the first delivered by King WillemAlexander. It was the third Dutch speech which promoted the candidature but the first to do so with explicit reference to the Kingdom of the Netherlands as comprising four autonomous countries. Three of the four countries of the Kingdom are small islands, especially vulnerable to the consequences of climate change and marine pollution. The Dutch experience of water management and the Netherlands as 'one of the best-protected deltas in the world' were also explicitly stated. Similar to the previous speeches in the UNGA, King Willem-Alexander spoke of peace, justice and development, and characterised them as 'a trinity — as tied to each other as the blade of a windmill' ${ }^{66}$

Similarly, the short texts and pamphlets of the Dutch campaign began by expressing a genuine interest in dialogue and partnership within the areas of peace, justice and development. The engagement of the Netherlands, as a founding member of the UN, and the Dutch contributions to the UN, especially within peacekeeping, were emphasised.

\footnotetext{
64 Timmermans 2013 .

65 Rutte 2014.

66 King Willem-Alexander 2015.
} 
Sweden and the Kingdom of the Netherlands displayed many similarities in their campaigning for a seat in the UNSC but there were also some notable differences.

With respect to organisation, for both campaigns the planning took place at a unit within the Foreign Ministry in the capital, with the mission in New York as the other important centre. Close contact and friendly collaboration between these two units were characteristic of both campaigns and both centres grew gradually in size as the campaign intensified. Both campaigns paid a lot of attention on seeking to estimate support on diplomatic and political levels. The Kingdom of the Netherlands began to organise earlier and ended up with a slightly larger staff in the capital and in New York.

With respect to key participants, both campaigns engaged diplomats, public officials and members of the government. Each campaign sought to involve members of the government and recruited senior diplomats and politicians to further increase the number of participants in the campaign. On certain occasions, they also included members of the royal family. On a few occasions, the Kingdom of the Netherlands also involved celebrities such as actors and athletes. In both campaigns, the Permanent Representative in New York was of key importance, paying multiple visits to colleagues to seek and estimate support from other Member States. During the concluding phase of the campaign, many different members of the Swedish government were actively involved in attending strategically selected events and travelled extensively. With the 2015 session in the UNGA as the rare exception, the Dutch campaign depended on contributions primarily from the Foreign Minister. During 2016, the Dutch Presidency of the EU placed demands on the time of other ministers. ${ }^{67}$

With respect to activities, both campaigns were very active in New York. For the bilateral approach with repeated visits by the Permanent Representative to colleagues, both missions had a strategy to prepare and follow up on each of these many meetings. Each campaign arranged events in New York for the purpose of attracting attention and displaying strong themes and contributions made by the candidate. Similar types of events also took place at embassies around the world, and at other Permanent Missions such as in Brussels. Both campaigns arranged visits to the capital for a targeted group of Permanent Representatives, who participated in seminars, did study visits and met with members of the royal family. The Swedish campaign was more active at multilateral meetings and was careful to ensure that the appropriate

67 Tahzib-Lie and Reinder Rosing 2019. 
member of government attended to promote the candidature, as well as to demonstrate interest and knowledge regarding selected themes of relevance to the campaign.

With respect to message, both campaigns emphasised a historic and present commitment to the United Nations, including economic contributions, operations, treaties, conferences and overall values, when presenting their UN CV. The Swedish campaign focused only on its merits for the entire first half of the active phase of campaigning, whereas the Kingdom of the Netherlands launched a slogan to summarise a campaign message almost three years ahead of the election. The Swedish message emerged later but both campaigns formulated a message on basis of their strongest multilateral merits. While both candidates had very strong merits, there also were relevant differences. While Sweden does not have an international city like The Hague, it could, and did, emphasise its commitment to aid and development by reference to a high ODA. Specifically, in 2015 ODA as percentage of gross national income was 0.75 per cent for the Kingdom of the Netherlands, and 1.40 per cent for Sweden. ${ }^{68}$

The comparison in this article identifies the more active participation by members of the government as a main difference between the two campaigns. Guided by the study's theoretical framework, the implications of this difference accounts for an explanation for Sweden's success in the 2016 election. To specify, the framework identifies the three campaigning logics: contributions, commitment and competence. The more active political participation gave the Swedish campaign a comparative advantage with regard to the logics of commitment and competence. To prove Swedish commitment to the candidature, it was especially useful that the Prime Minister actively participated in the campaign, thereby underlining firm dedication on behalf of the highest political office. To underline the relevant skills and competence, it was useful to the Swedish candidature that the remaining active members of the government had portfolios which corresponded closely to the themes and challenges identified by the message of the campaign. This contributed towards displaying expertise relevant to the values, themes and challenges highlighted by the message.

In sum, while both countries convincingly demonstrated their past and current contributions to the UN, and the Netherlands much earlier than Sweden, the more active participation by members of the government enabled the Swedish campaign to make a more convincing case with regard to commitment and competence. 
A non-permanent seat in the Security Council provides states with an attractive opportunity for international representation. Elections with contested slates imply intense competition between candidates. From previous results, it is well known that wealthy and populous countries have an advantage but early 'strong' favourites may still suffer a tough loss, and being a first-time candidate may be beneficial. This article has argued that differences in the campaigning may be decisive for the outcome, especially between candidates with similar qualities. Especially, this comparative study of the Dutch and Swedish campaigns for a seat in the Security Council identifies active political participation as crucial. One main difference detected between the campaigns by Sweden and the Kingdom of the Netherlands which constitutes an advantage for the Swedish campaign was more frequent participation by several members of the government, including the Prime Minister. Other detected differences, including a quick start to reach vote exchange agreements and an early launch of active campaigning, should rather have been advantages for the Dutch campaign. Successful campaigning seems to require that members of government are prepared to actively promote the candidature at multilateral events and through bilateral dialogue. To be convincing, a campaign has to demonstrate activity on the highest political level. Thus, the clear policy implication from this study is that decision-making on whether to a launch a candidature or not should take into account if the leading politicians will be prepared to become actively involved in the campaign. Foreign policy making is always a matter of priorities. A candidature for a non-permanent seat not only requires resources but also that politicians invest time and engagement. On the other hand, a loss in the UNSC election, for a lack of commitment or other reasons, is a political setback. If leading politicians have a low level of commitment, it might be better to refrain from the candidature.

This article suggests that future empirical studies assess the relevance of political commitment as a defining factor for success in international campaigning. This comparative study, like earlier single case studies, focusses on the electoral competition between candidates from the WEOG. It would be interesting to apply this framework not only to more cases in the WEOG but also to campaigns by candidates from other regional groups. An additional way to further evaluate the usefulness of the framework would be to apply it to campaigns for positions other than non-permanent seats in the Security Council; for example, to seats on the Human Rights Council, or positions in international organisations other than the United Nations. 


\section{Bibliography}

Byrne, Caitlin. 'Campaigning for a Seat on the Security Council: A Middle Power Reflection on the Role of Public Diplomacy'. CDP Perspectives on Public Diplomacy, Paper 10 (2011).

Chapnick, Adam, Canada on the United Nations Security Council: A Small Power on a Large Stage (Vancouver, Canada: UBC Press, 2019).

Copeland, Daryl. 'Multilateral Diplomacy, the United Nations Security Council, and Canadian Foreign Policy: Stormy Weather?' Behind the Headlines 56 (3) (1999), 2-5.

Copeland, Daryl. 'What Canada's Security Council Loss Says about Us'. The Mark, 16 October 2010.

Cronenberg-Mossberg, Ulrika. 'Uppföljning och utvärdering av kampanjen för Sveriges kandidatur till FN:s säkerhetsråd' [Assessment of the Swedish Campaign to the UN Security Council] (Stockholm: Riksdagens utrikesutskott, 2017).

Dreher, Axel, Matthew Gould, Matthew D. Rablen and James Raymond Vreeland. 'The Determinants of Election to the United Nations Security Council'. Public Choice $15^{8}$ (2014), 51-83.

Ekengren, Ann-Marie, Fredrik D. Hjorthen and Ulrika Möller. 'A Nonpermanent Seat in the United Nations Security Council: Why Bother?' Global Governance 26 (1) (2020), 21-45.

Gillissen, Christophe. 'The Back to the Future? Ireland at the UN Security Council, 2001-2002'. Nordic Irish Studies 5 (1) (2006), 23-40.

Government Declaration (Sweden). 'Regeringsförklaringen, 3 oktober 2014'. October 2014.

Grunditz, Mårten. 'Statement by H.E. Mr. Mårten Grunditz Permanent Representative of Sweden to the United Nations at the General Debate of the 6gth Session of the General Assembly'. 29 September 2014.

Herrnson Paul S. 'The Roles of Party Organizations, Party-Connected Committees, and Party Allies in Elections'. Journal of Politics 71 (4) (2009), 1207-1224.

International Peace Institute. 'Taking Stock, Moving Forward'. Research Report (New York: International Peace Institute, 2012).

Kennedy, Michael and Deirdre McMahon, eds. Obligations and Responsibilities: Ireland and the United Nations, 1955-2005: Essays Marking Fifty Years of Ireland's United Nations Membership (Dublin: Institute of Public Administration, 2005).

King Willem-Alexander. 'Speech by His Majesty King Willem-Alexander at the 7oth Session of the United Nations General Assembly'. 28 September 2015.

Langmore, John. 'Australia's Campaign for Security Council Membership'. Australian Journal of Political Science 48 (1) (2013), 101-111. 
Langmore, John and Jeremy Farrall. 'Can Elected Members Make a Difference in the Security Council? Australia's Experience in 2013-2014'. Global Governance 22 (1) (2016), 59-77.

Lidén, Anders. 'Report to the Swedish Foreign Ministry Regarding the Swedish Campaign to the UNSC' (Unpublished Report, 2016).

Löfven, Stefan. 'Statement by H.E. Mr. Stefan Löfven. Prime Minister of Sweden, at the General Debate of the 7oth Session of the General Assembly'. 30 September 2015 .

Löfven, Stefan and Urban Ahlin. 'Sveriges röst måste bli tydlig och stark i FN' [The Swedish Voice in the UN Has to Be Clear and Strong']. Dagens Nyheter, 8 October 2013.

Lowy Institute. Lowy Diplomacy Index. 2016.

Maas Weigert, Kathleen and Robert E. Riggs. 'Africa and United Nations Elections: An Aggregate Data Analysis'. International Organization 23 (1) (1969), 1-19.

Malone, David. 'Eyes on the Prize: The Quest for Nonpermanent Seats on the UN Security Council'. Global Governance 6 (1) (2000), 3-23.

Melissen, Jan. 'Diplomatic Studies in the Right Season'. International Studies Review 13 (2011), 709-728.

Neumayer, Eric. 'Distance, Power and Ideology: Diplomatic Representation in a World of Nation-States'. Area 40 (2) (2008), 228-236.

O’Brien, Terrence. 'Getting around the Security Council Table'. New Zealand International Review 40 (1) (2015), 6-8.

oECD (Organisation for Economic Co-operation and Development). 'Development Co-operation Profiles 2O2O'. Research Report (Paris: OECD, 2O2O).

O'Shaughnessy, Nicholas J. The Idea of Political Marketing (Westport, CT: Praeger, 2002).

Panebianco, Angelo. A Political Parties: Organization and Power (New York: Cambridge University Press, 1988).

Persson, Christer. 'The Olympic Games Site Decision'. Tourism Management 23 (1) (2000), 27-36.

Rutte, Mark. 'Address to the 69th Session of the United Nations General Assembly by H.E. Mark Rutte Prime Minister of the Kingdom of the Netherlands'. 25 September 2014.

Security Council Report. 'Security Council Elections 2016'. 31 May 2016.

Sievers, Lorraine and Sam Daws. The Procedure of the UN Security Council, 4th ed. (Oxford: Oxford University Press, 2014).

Singer, Marshall R. and Barton Sensenig. 'Elections within the United Nations: An Experimental Study Utilizing Statistical Analysis'. International Organization 17 (4) (1963), 901-925. 
Stylianides, Christos. 'The Netherland Candidate for the UN Security Council: Koenders Addresses Diplomats', Diplomat Magazine (4) (2016), 12-14.

Sussman, Gerald Global Electioneering: Campaign Consulting, Communications, and Corporate Financing (Oxford: Rowman and Littlefield, 2005).

Tahzib-Lie, Bahia and Jan Reinder Rosing. 'A Competitive Race among Friends: The Campaign of the Kingdom of the Netherlands for a Seat on the UN Security Council'. The Hague Journal of Diplomacy 14 (4) (2019), 467-479.

Thakur, Ramesh. 'Australia's Unsuccessful Bid for the UN Security Council'. Pacific Research 9 (4) (1996), 48-49.

Thorhallsson, Baldur and Anna Maria Eggertsdóttir. 'Small States in the UN Security Council: Austria's Quest to Maintain Status'. The Hague Journal of Diplomacy 16 (1) (2021), this issue. DoI: 10.1163/1871191X-BJA10o17.

Timmermans, Frans. 'Address to the 68th Session of the United Nations General Assembly by H.E. Frans Timmermans Minister of Foreign Affairs of the Netherlands'. 27 September 2013.

Van der Brug, Wouter and Anthony Mughan. 'Charisma, Leader Effects and Support for Right-Wing Populist Parties'. Party Politics 13 (1) (2007), 29-51.

Whelan, Mary. 'Ireland's Campaign for Election in 2000 to the United Nations Security Council'. Administration 5o (1) (2002), 3-40.

Wiseman, Geoffrey. 'Bringing Diplomacy Back in: Time for Theory to Catch up with Practice'. International Studies Review 13 (2011), 709-728.

\section{Ann-Marie Ekengren}

is Professor of Political Science at the University of Gothenburg, Sweden. Her field of expertise is foreign policy making: the mediatisation of foreign policy making, foreign policy roles and partisan aspects of foreign policy making. She has published in journals such as International Studies Quarterly, Cooperation and Conflict, Party Politics and Global Governance. She is Co-Author (with Douglas Brommesson) of The Mediatization of Foreign Policy, Political DecisionMaking and Humanitarian Intervention (Palgrave Macmillan 2017).

\section{Ulrika Möller}

is Assistant Professor of Political Science at the University of Gothenburg, Sweden. Her field of expertise includes Swedish foreign policy, nuclear nonproliferation and disarmament, and political leadership and democratisation. She has published in journals such as Cooperation and Conflict and Global Governance. 